\title{
ROLE OF EMERICELLA NIDULANS AND EPICOCCUM NIGRUM IN CONTROLLING SUGER BEET LEAF SPOT DISEASE
}

\author{
Esh, A.M.H* and Shadia Taghian \\ Sugar Crops Research Institute, Agricultural Research Centre, Giza, Egypt \\ *Corresponding author's E-mail: aymanesh@gmail.com
}

Submitted August 16, 2021; Accepted October 13, 2021; Published November 21, 2021

\section{SYMMARY}

Two fungal isolates from commercial sugar beet phyllospher in Kafr-Elshaikh governorate, Egypt were tested for its antagonistic activity against Cercospora beticola the causal pathogen of sugar beet cercosporia leaf spot (CLS) disease in vitro.

Three methods were used to evaluate its antagonistic activity (Conventionalstreak, culture filtrates and volatile gases). The ability of the tested isolates to produce PR-proteins and growth-promoter indole acetic acid were studied. The tested isolates Emericella nidulans (Aspergillus nidulans) and Epicoccum nigrum found to have the potential to produce chitinase and $\beta-1,3$ glucanase while Emericella nidulansthe only found to have the potential to produce indole acetic acid (IAA). The tested fungal isolates showed a remarkable antagonistic activity in both green-house and open field against C. beticola compared with the healthy control and the infected control.

Also it was found that the control efficiency of the two isolates was almost equivalent to the tested fungicide. The present data show that phyllospheric fungi can play as a good candidate to be used as a bio-control agent against sugar beet leaf spot disease.

Key words: Phyllospheric fungi, Antagonism, Chitinase, $\beta$ 1, 3 glucanase, Indole acetic acid (IAA) and Salicylic acid (SA).

\section{Introduction}

Epiphytic microbes have been documented for numerous phyllosphereand rhizosphere inhabiting organisms and/or stimulating the induction of systemic resistance mechanisms within the plant (Bargabus et al. 2002). Filamentous fungi (Punja and Utkhede, 2003), and Oomycetes (Picard et al., 2000) have been employed as biological control agents. Bio-control agents can be effective through the production of hydrolytic enzymes and antibiotics, niche colonization and competition for host nutrients, induction of plant host defense mechanisms, and interference with pathogenicity factors (Punja and Utkhede, 2003). Integration of Bacillus-based biological control agents (BCAs) with breeding for disease resistance has proven to be useful in management of several disease problems, particularly where high yielding; highly resistant cultivars are not available. Jacobsen et al., (2002). Larson, (2004) published examples include Cercospora leaf spot(CLS) of sugar beet and other plant diseases they revealed that, disease control involving a Bacillusbased bio-control was better on the more resistant cultivars. Larenaa et al., (2005) E. nigrum application, alone or in combination with fungicides can be considered in a disease control strategy for reducing fungicide treatments and residues. A further reduction of brown rot may be possible by a better formulation of the biological product. Since fungicides may affect human health and the environment and since pathogens can develop resistance to fungicides, the attention to environmentally friendly alternatives to the use of chemical pesticides as biological control of cercospora has begun. Epiphytic microbes has been documented for numerous phyllosphere and rhizosphere inhabiting organisms and/or stimulating the induction of systemic resistance mechanisms within the plant (Bargabus et al., 2002).

\section{Materials and Methods}

\section{1- Isolates source:}

Phyllospheric fungiisolates Emericella nidulans (Aspergillus nidulans) and Epicoccum nigrum were obtained from the isolates collection of Plant pathology laboratory, Sugar Crops Research Institute, ARC. The isolates were obtained from a former survey of phyllosphieric fungi of sugar beet in Egypt.

\section{2- Source of Cercospora beticola isolate:}

A virulent isolate of $C$. beticola (isolated from Kafr El-Sheikh) was obtained from the Cercospora collection in the Department of Sugar Crops Pest and Diseases, Sugar Crops Research Institute, ARC, Giza to be use in this study.

\section{3-Antagonistic effect of the different tested fungi on linier growth of Cercospora beticola in vitro: \\ The possible antagonistic potential of fungal isolates against $\mathrm{C}$. beticola was studied using different dual culture techniques.}




\subsection{Conventional streak method:}

The possible antagonistic potential of the different phyllosphric microorganism isolate against C. beticola was studied as described by (Douglas et al., 2003).Petri-dishes ( $9 \mathrm{~cm}$ in diameter) containing $10 \mathrm{ml}$ of the PDA medium were inoculated with a disk of C. beticola (5.0-mm in diameter) obtained from the margin of an actively growing 14 days old culture of $C$. beticola placed on one edge of a $9 \mathrm{~cm}$ in diameter Petri-dish containing PDA medium, while the tested fungal isolate placed on the opposite side of the plate. The plates incubated at $28 \pm 2{ }^{\circ} \mathrm{C}$ for 30 days under weekly observations. At the end of incubation period when the growth of the control reach $9 \mathrm{~cm}$ diameter, the average of longest and shortest diameter of Cercospora colony was measured in the treated plates.

The antagonistic potential of the bio-agents expressed according to the following formula:

Antagonistic potential $(\%)=[(C-T) \backslash C] X 100$

Where: $\mathrm{C}=$ diameter of radial growth of the pathogenic fungus on plates containing it only, $\mathrm{T}=$ diameter of radial growth of the pathogenic fungus on plates paired with each antagonistic fungus (dual cultures).

\subsection{Effect of volatile gases produced by tested fungal bio-agents on the growth of Cercospora beticola(in vitro):}

A discs ( $0.5 \mathrm{~cm}$ in diameter) of Cercospora isolate and the fungal isolates obtained from the margin of an actively growing 14 days old culture of each culture were inoculated in the center of a separate petri-dishes containing PDA medium. Under aseptic conditions both half plates of cercospora and tested fungal isolates were placed face to face without any physical contact between the inoculum, then sealed using parafilm to isolate the inside atmosphere and to prevent loss of volatiles formed (Fig. 2). Plates were incubated at $28 \pm 2{ }^{\circ} \mathrm{Cfor} 30$ days and the liner growth of C. beticola was measured and compared to controls developed at the same condition with absence of the bio-antagonist (mocked inoculation with an 5.0-mm disk of PDA) (Montealegre, et al., 2003). Each experiment considering a single fungal isolate was run in triplicate.

\subsection{Effect of culture filtrates of the selected fungal isolates on the growth of C. beticola (in vitro):}

The tested fungal isolates Emericella nidulans and Epicoccum nigrumwere grown in $250 \mathrm{ml}$ containing sterilized $100 \mathrm{ml}$ potato dextrose broth (PDB) then incubated at $28 \pm 2{ }^{\circ} \mathrm{Cfor} 7$ days. The growth mass was picked up and then the supernatant centrifuged and filter sterilized as mentioned before. The sterile fungal filtrates mixed (1:1) with warm PDA medium then inoculated with $\mathrm{C}$. beticolaas mentioned above. The inoculated plates were incubated at $28 \pm 2^{\circ} \mathrm{Cfor}$ 30 days. The liner growth of $\mathrm{C}$. beticola was measured compared to the control treatment to calculate the percentage in growth reduction.

\section{Physiological studies on the tested fungi isolates: 4.1. Indole acetic acid production (IAA):}

To determine the ability of the tested fungal isolates Emericella nidulansand Epicoccum nigrumto produce IAA, a colorimetric technique (Bric et al., 1991) was performed using the Van Urk Salkowski reagent $\left(1 \mathrm{ml}\right.$ of $0.5 \mathrm{M} \mathrm{FeCl}_{3}$ and $50 \mathrm{ml}$ of $35 \%$ $\mathrm{HClO}_{4}$ in water); the tested fungi were grown in liquid Czapek-Dox containing 0.2\% L-tryptophan, and incubated at a $28^{\circ} \mathrm{C}$ for $24 \mathrm{hr}$. After the incubation time cultures were centrifuged (1000 rpm) then $1 \mathrm{ml}$ of the supernatant mixed with $2 \mathrm{ml}$ of the reagent and incubated for $25 \mathrm{~min}$. at room temperature. The optical density was measured using the wave length $530 \mathrm{~nm}$. A standard curve of pure IAA (Sigma-Aldrich) was used as standard to calculated IAA production from tested isolates.

\subsection{Chitinase production:}

The tested fungi isolates Emericella nidulansand Epicoccum nigrum were cultured in $250 \mathrm{ml}$ conical flasks containing $50 \mathrm{ml}$ of liquid Czapek-Dox for fungal isolates supplemented with $0.2 \%$ sucrose and $0.2 \%$ colloidal chitin was prepared according to the method of Campell and Williams (1951). The fungal isolates incubated at $28^{\circ} \mathrm{Cfor} 7$ days on a rotary shaker incubator. After the incubation period the cultures were centrifuged at $10000 \mathrm{rpm}$ for $20 \mathrm{~min}$. at $4^{\circ} \mathrm{C}$ and the supernatant was used as crude enzyme source. A mixture of crude enzyme source $(1 \mathrm{ml})$ and suspension of colloidal chitin $(1 \mathrm{ml} ; 0.1 \%$ in $50 \mathrm{~mm}$ sodium acetate buffer; $\mathrm{pH} 5$ ) was incubated at $38^{\circ} \mathrm{C}$ in a water bath with constant shaking. After $2 \mathrm{hr}$., the release of $\mathrm{N}$-acetyl-glucosamine in the reaction mixture was estimated by the method of Reissig et al., (1955). The enzyme activity was determined using N-acetyl-glucosamine (Sigma) as the standard. Absorbance was measured at $660 \mathrm{~nm}$ using a Milton Roy Spectronic 1201. One unit of Chitinase is defined as the amount of enzyme producing $1 \mu \mathrm{mol}$ $\mathrm{N}$-acetyl-glucosamine/min in $1 \mathrm{ml}$ of reaction mixture under standard assay conditions. Specific activity was expressed as $\mu \mathrm{g}$ of glucose released / $\mathrm{ml}$ /min. 4.3. $\beta-1,3$ glucanase production.

Theisolate were grown in $250 \mathrm{ml}$ conical flasks containing $50 \mathrm{ml}$ of liquid Czapek-Dox both media contained laminarin $(0.2 \%)$ (From Laminaria digitata; Sigma) Lim et al., (1991), incubated at 7 days on a rotary shaker incubator. The cultures then centrifuged as previously mentioned and the resulted supernatant used as crude enzyme source. The reaction mixture was the substrate laminarin (SigmaAldrich) $(2.5 \% \mathrm{w} / \mathrm{v})$ in $10 \mathrm{~mm}$ ammonium acetate, $\mathrm{pH} 6.0$, and $1 \mathrm{~mm}$ DTT. The reaction incubated at room temperature for $24 \mathrm{~h}$. Samples were assayed for the release of reducing sugars according to the Smoggy-Nelson method Nelson, (1944) modified by (Naguib 1964 and 1965). Absorbance was measured at $660 \mathrm{~nm}$ using a Milton Roy Spectronic 1201. Standard curve of glucose was used as reference 
(Lim et al., 1991). $\quad \beta 1,3$ glucanase activity was determined as $\mu \mathrm{g}$ of glucose released $/ \mathrm{ml} / \mathrm{min}$.

\section{Antagonistic effect of the isolate on cercospora leaf spot incidence in vivo during the season 2018 - 2019 Inoculum preparation:}

5.1. Preparation of fungal isolates (bio-agent) inoculums:

After the incubation period (7days) the fungal cultures were blinded separately in a partially sterilized electrical blinder (using ethanol $70 \%$ ) for 5 min. The fungal suspensions then diluted by sterilized distilled water up to $1000 \mathrm{ml}$ with adding $0.1 \mathrm{ml}$ Tween- 80 as described by Esh, (2005) to be ready to spray on the experimental plants.

\subsection{Preparation of Cercospora beticola Inoculum:}

Colonies of $\mathrm{C}$. beticola 30-days old culture were flooded with $10 \mathrm{ml}$ sterile distilled water and rubbed with a glass rod. One milliliter of this suspension used to inoculate $500 \mathrm{ml}$ conical flasks containing $250 \mathrm{ml}$ of sugar beet leaf broth (SBLB) medium then incubated at $28 \pm 2^{\circ} \mathrm{Cunder}$ a $16-\mathrm{hr}$ photoperiod (fluorescent lights) for 30 days. After incubation cultures were blinded separately in a partial sterilized (by ethanol 70\%) electrical blinder for $5 \mathrm{~min}$.
The fungal suspension then diluted by distilled water to reach $3 \times 10^{4} \mathrm{cfu} / \mathrm{ml}$ to spray on the experimental plants. (Vereijssen et al., 2003 and Esh, 2005).

\subsection{Inoculation of sugar beet plants:}

Sugar beet plants were grown in $30 \mathrm{~cm}$ diameter pots filled with $3 \mathrm{~kg}$ (sand: peat moss: clay soil) (1:1:1).Sugar beet plants variety Kawmera (16 weeks old) were treated by the tested phyllospheric bacteria and fungi 2 times before inoculation with $\mathrm{C}$. beticola in 7 days intervals. One week after the last treatment the conidial suspension $3 \times 10^{4} \mathrm{cfu} / \mathrm{ml}$ ofC. beticola was prepared and atomized on sugar beet leaves from all directions until run off. After inoculation, plants were irrigated and covered with transparent plastic bags to serve as a moist chamber and the greenhouse fog system was kept (fig. 3) running for 5-days. Both procedures were to increase the greenhouse humidity to above $90 \%$. After 5 days, the plastic sheets removed, and plants kept on the bench to allow disease development (Esh, 2005).

The disease severity was calculated according to the discretional Battilani key for disease assessment of cercospora leaf spot disease.

\section{Table (1): Battilani key for disease assessment of cercospora leaf spot disease on sugar beet}

\begin{tabular}{|c|c|c|c|}
\hline$\overline{\text { Deg. }}$ & Description & Deg. & Description \\
\hline 0 & Healthy foliage & 3 & $\begin{array}{l}\text { Fully and almost fully grown leaves show several } \\
\text { coalesced necrotic areas of } 1-2 \mathrm{~cm} \text { diameter, that } \\
\text { don't lead to large necrotic areas.. }\end{array}$ \\
\hline 0.5 & A single isolated spot on some leaves. & 3.5 & $\begin{array}{l}\text { Some } 2-4 \text { outer leaves show relatively large } \\
\text { necrotic areas }(20-30 \%) \text { of the leaf area. }\end{array}$ \\
\hline 1 & $\begin{array}{l}50 \% \text { of the outer leaves (fully grown or old) } \\
\text { show one to a few spots (20). Coalescence of } \\
\text { maximum } 2 \text { spots can appear. }\end{array}$ & 4 & $\begin{array}{l}\text { For the first time some leaves }(2-8) \text { show } 80 \text { to } \\
100 \% \text { severity. }\end{array}$ \\
\hline 1.5 & $\begin{array}{l}\text { Outer leaves ( } 50 \% \text { of foliage) show } 20 \text { to } 200 \\
\text { spots per leaf. Coalescence of maximum } 2 \\
\text { spots can appear. }\end{array}$ & 4.5 & The entire foliage is strongly affected. \\
\hline 2 & $\begin{array}{l}\text { Nearly all outer leaves are affected by several } \\
\text { spots, still isolated. Coalescence } \\
\text { of maximum } 2 \text { spots can appear. }\end{array}$ & 5 & The original foliage is completely destroyed. \\
\hline 2.5 & $\begin{array}{l}\text { Some (2-4) outer leaves show coalescence of } \\
\text { spots to necrotic areas. First spots appear on } \\
\text { inner leaves }\end{array}$ & 6 & $\begin{array}{l}\text { For every week scale, } 5 \text { continuous } 1.5 \text { is added. } \\
\text { This phase shows flushes of growth, which can be } \\
\text { affected in turn. }\end{array}$ \\
\hline
\end{tabular}

6. Effect of bio-agent application on some compounds related to induce resistance in vivo under greenhouse condition:

\subsection{Preparation of enzyme source:}

Leaf samples were collected from treated sugar beet plants variety (Kawmera) with the promising bio-control active candidates of phyllospheric fungal isolate two weeks before the artificial infection with Cercospora beticola under greenhouse conditions. Samples were frozen in liquid nitrogen $\left(\mathrm{L}-\mathrm{N}_{2}\right)$ then grounded in a mortar and pestle to form a fine powder.
One gram of the grounded tissues was mixed with $2 \mathrm{ml}$ of extraction buffer according to Bollag et al., (1996). Samples were vortexes and centrifuged at $13000 \mathrm{rpm}$ for $15 \mathrm{~min}$. under $4^{\circ} \mathrm{C}$ to remove cell debris. The clear supernatant (crude enzyme source) was collected and kept at $-80^{\circ} \mathrm{C}$ for further study. (Soltis and Pamela Soltis, 1990).

\subsection{Chitinase production:}

The supernatant was used as crude enzyme source. A mixture of crude enzyme source $(1 \mathrm{ml})$ and suspension of colloidal chitin $(1 \mathrm{ml} ; 0.1 \%$ in $50 \mathrm{~mm}$ sodium acetate buffer; $\mathrm{pH} 5$ ) was incubated at $38^{\circ} \mathrm{C}$ 
in a water bath with constant shaking. After $2 \mathrm{hr}$., the release of $\mathrm{N}$-acetyl-glucosamine in the reaction mixture was estimated by the method of Reissig et al., (1955). The enzyme activity was determined using N-acetyl-glucosamine (Sigma) as the standard. Absorbance was measured at $660 \mathrm{~nm}$ using a Milton Roy Spectronic 1201. One unit of chitinase is defined as the amount of enzyme producing $1 \mu \mathrm{mol}$ $\mathrm{N}$-acetyl-glucosamine/min in $1 \mathrm{ml}$ of reaction mixture under standard assay conditions. Specific activity was expressed as $\mu \mathrm{g}$ of glucose released / $\mathrm{ml}$ /min.

\section{3. $\beta-1,3$ glucanase production:}

The resulted supernatant used as crude enzyme source. The reaction mixture was the substrate laminarin (Sigma-Aldrich) $(2.5 \% \mathrm{w} / \mathrm{v})$ in $10 \mathrm{~mm}$ ammonium acetate, $\mathrm{pH} 6.0$, and $1 \mathrm{~mm}$ DTT. The reaction incubated at room temperature for $24 \mathrm{~h}$. Samples were assayed for the release of reducing sugars according to the Smoggy-Nelson method Nelson, (1944) modified by (Naguib 1965). Absorbance was measured at $660 \mathrm{~nm}$ using a Milton Roy Spectronic 1201. Standard curve of glucose was used as reference (Lim et al., 1991). $\beta$ 1,3 glucanase activity was determined as $\mu \mathrm{g}$ of glucose released / $\mathrm{ml} / \mathrm{min}$.

\subsection{Determination of peroxidase (PO):}

The reaction mixture extraction as described by Malik and Singh, (1990) was contained $0.5 \mathrm{ml}$ phosphate buffer $\mathrm{pH} 7 ; 0.2 \mathrm{ml}$ enzyme source; $0.3 \mathrm{ml}$ of $0.05 \mathrm{M}$ pyrogallol; $0.1 \mathrm{ml}$ of $1 \%(\mathrm{v} / \mathrm{v}) \mathrm{H}_{2} \mathrm{O}_{2}$ and distilled water was added up to obtained $3 \mathrm{ml}$. The reaction mixture was incubated at $30{ }^{\circ} \mathrm{C}$ for $5 \mathrm{~min}$. then the reaction stopped by adding $0.5 \mathrm{ml}$ of 5 $\%$ (v/v) $\mathrm{H}_{2} \mathrm{O}_{2}$ (Kar and Mishra, 1976). One unit of peroxidase activity was expressed as the changes in absorbance at $425 \mathrm{~nm} / \mathrm{min}$. / $1 \mathrm{~g}$ fresh weight.

\subsection{Polyphenol oxidase (PPO):}

Samples were extracted according to the method described by Malik and Singh, (1990). The enzyme extract was prepared by grounding $5 \mathrm{~g}$ leaves in 0.1 $\mathrm{M}$ sodium phosphate buffer $\mathrm{pH} 7(2 \mathrm{ml} / \mathrm{g}$ fresh weight), then centrifuged at $6000 \mathrm{rpm}$ for $30 \mathrm{~min}$.
Under $4{ }^{\circ} \mathrm{C}$, the clear extract was collected, completed to $15 \mathrm{ml}$ volume using phosphate buffer and used as crude enzyme source. The reaction mixture contained $0.2 \mathrm{ml}$ of crude enzyme source, 1 $\mathrm{ml}$ of phosphate buffer $\mathrm{pH} \mathrm{7;1} \mathrm{ml}$ of $10^{-3} \mathrm{M}$ catechol and complete with distilled water up to $6 \mathrm{ml}$.

The reaction was incubated for $30 \mathrm{~min}$. at $30{ }^{\circ} \mathrm{C}$. One unite of polyphenol oxidase was expressed as the change in absorbance at $420 \mathrm{~nm} / 30 \mathrm{~min}$. / $1 \mathrm{~g}$ fresh weight (Matta and Dimond, 1963).

\section{7-Effect of bio-agent application on disease incidence under field condition during the season 2019-2020:}

The same procedure and sugar beet variety used in the greenhouse experiment was used in the field trails, Sakha Experimental Station, Kafr El-Shaikh. The only difference was that after inoculation with $\mathrm{C}$. beticola the plants were left for the natural environmental conditions without covering the plants with plastic bags after the inoculation.

\section{RESULTS}

1-Effect of different methods of duel culture from Emericella nidulans and Epicoccum nigrum isolates on the liner growth of Cercospora beticola (in vitro):

Three methods were used to test the antagonistic activity (bio-control agent activity, BCA) of Conventional streak method, culture filtrate and volatile gases). Data in Fig. (1) Show that, the reaction of the bio- agent and the pathogen differed by the tested methods. In the conventional streak method isolates Emericella nidulans and Epicoccum nigrum significantly inhibited the liner growth of $\mathrm{C}$. beticola by ( 85 and $28 \%$ respectively), while, Emericellanidulans and Epicoccumnigrum in the volatile gases (69.4 and $52.8 \%$ respectively) significantly inhibited the liner growth of C. beticola .on the other hand, the method of culture filtrate gave no significant percentage of inhibition of C. beticola growth.

It was found that the results of the Conventional streak method were more accurate and reliable than the other used methods.

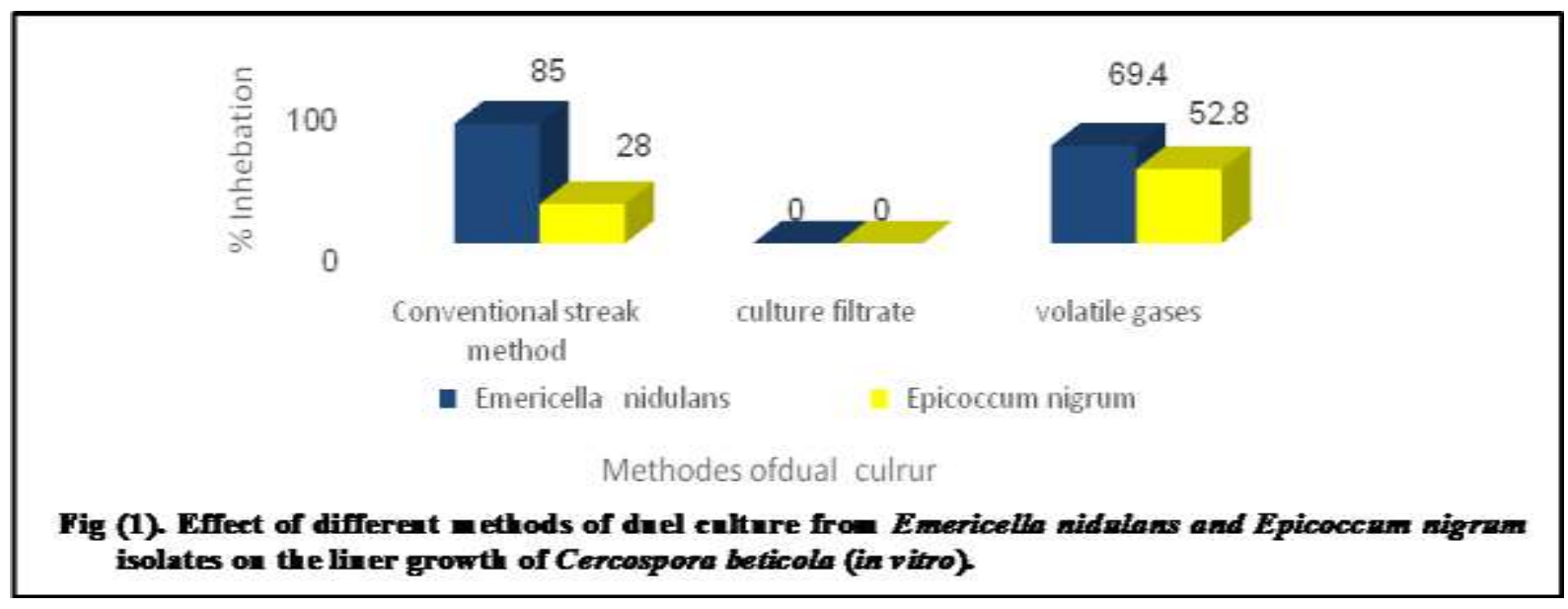




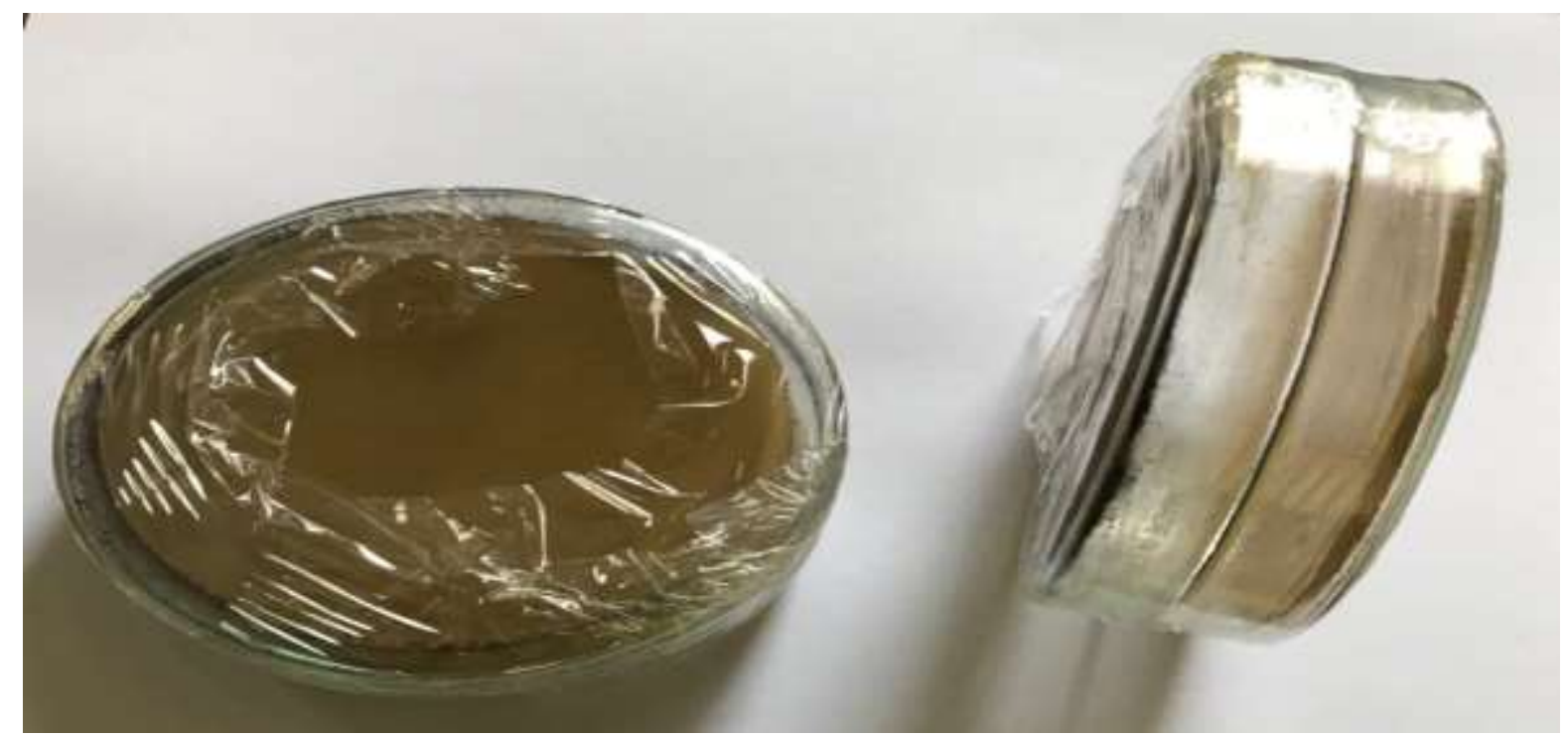

Fig (2) Effect of volatile gases produced by the tested bacterial bio-agents in inverted dual culture plates on the growth of Cercospora beticola(in vitro)
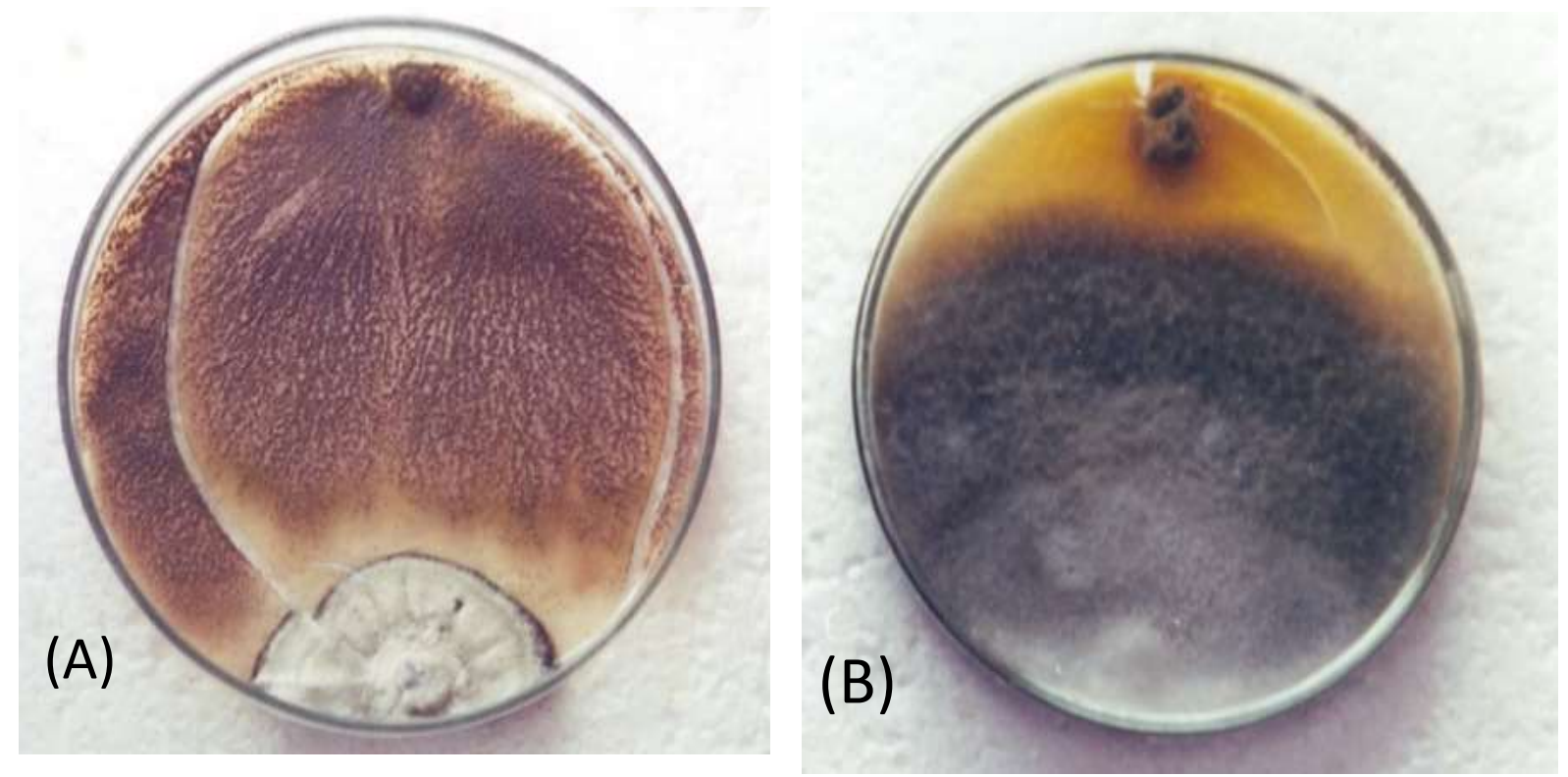

Fig (3) Antagonisticeffectof the isolates on Cercosporabeticolagrowthinvitro using (A) Emericella nidulans (85\%) and (B) Epicoccum nigrum (28\%)

\section{2-Physiological studies on the selected bio-agents in} vitro:

Emericella nidulans produced the significant highest IAA amount $(110 \mu \mathrm{g} / \mathrm{ml}$, $)$ while the other isolate (Epicoccum nigrum) didn't produce any IAA.

The obtained results showed that, the tested fungal isolates had the ability to hydrolyze Chitin in the chitin medium (fig.4). The enzyme activity differed significantly between the two fungal isolates. Isolate Emericella nidulans produced chitinase with in the medium amended with the substrate.

It is noticed that, the activity levels of the tested enzyme was significantly higher in the Epicoccum nigrum isolates $(83.3 \mu \mathrm{g}$ of glucose released $/ \mathrm{ml}$ /min.) compared to Emericella nidulans isolate (78.4 $\mu \mathrm{g}$ of glucose released / $\mathrm{ml} / \mathrm{min}$.). 


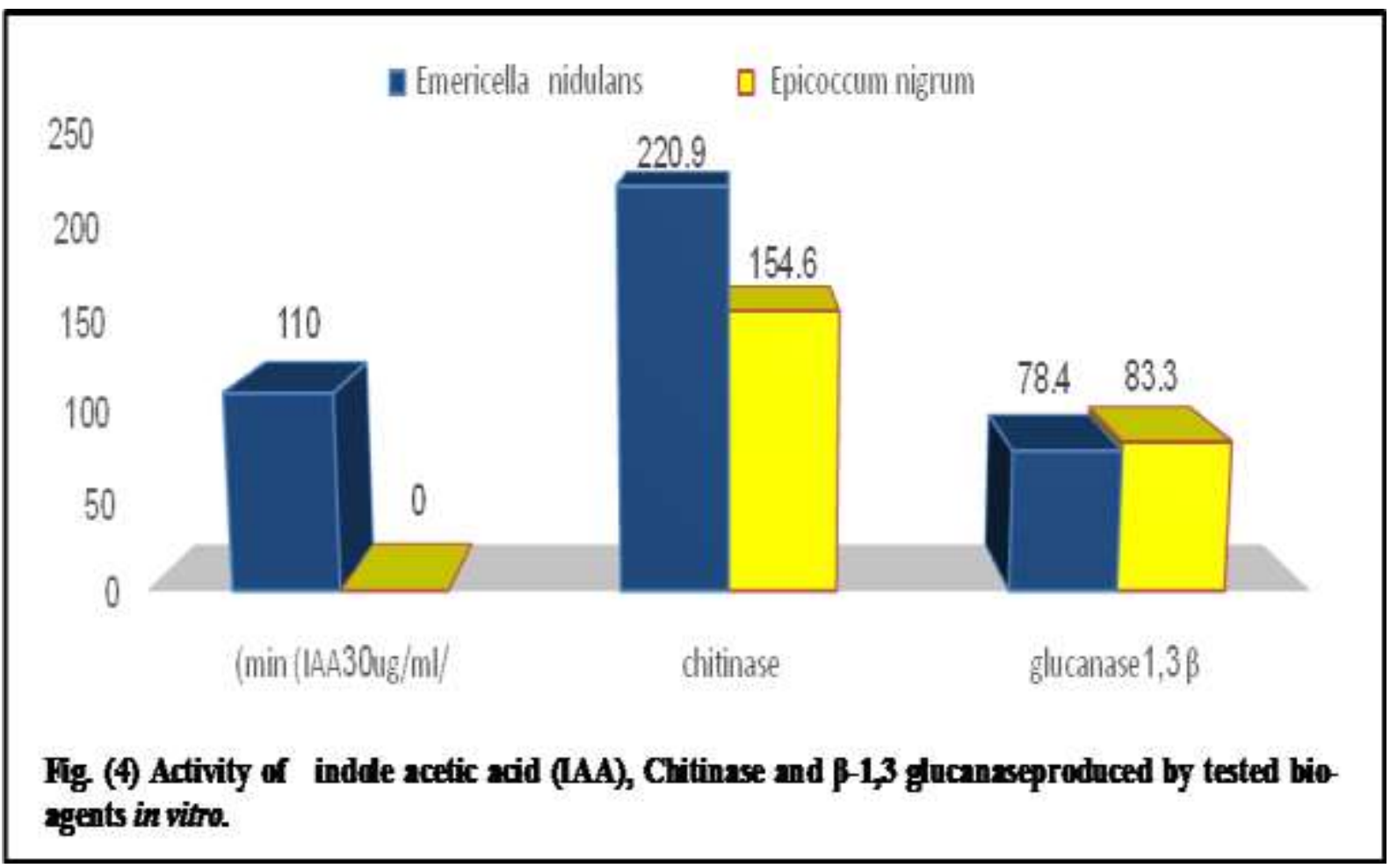

3- Effect of bio-agent application on disease incidence in- vivo under greenhouse condition:

3.1. Effect of bio-agents on disease severity under greenhouse condition:

The results presented in Table (2) show that Emericellanidulans and Epicoccumnigrum reduced the disease severity to (1.00 and 2.67 respectively)

compared to the untreated control treatment which recorded 4.66. It is worthy to mention that the reduction in disease severity (1.8) caused by the fungicide (Topsin M70) treatment has no significant difference compared to the reduction caused by the bio-agents treatment.

Table (2): Efficiency evaluation of the candidate phyllospheric fungal isolates on decreasing the severity of sugar beet cercospora leaf spot disease on sugar beet variety (Kawmera) when sprayed twice before artificial infection by Cercospora beticola under greenhouse conditions during the season 2018 -2019

\begin{tabular}{lcc}
\hline Fungal isolates & Disease severity & \% of disease inhibition \\
\hline Emericella nidulans & 1.00 & 78.54 \\
Epicoccum nigrum & 2.67 & 42.70 \\
Topsin M70 & 1.80 & 61.37 \\
Infected control & 4.66 & - \\
LSD at 0.05 & 1.7 & -
\end{tabular}

3.2.-Effect of application with the bio-agent on some compounds related to induce resistance in sugar beet plants:

The highest PO activity was recorded by the isolate Epicoccum nigrum (1.49 unite/30 min. /g and 1.5 unite/30 $\mathrm{min}$. /g fresh weight) (Fig 5).

On the other hand, the isolate Epicoccum nigrum recorded the highest PPO activity (0.32 unite/30 min. /g fresh weight.) while isolate Emericella nidulans fresh weight) followed by Emericella nidulans which recorded a lower activity (1.11 unite/30 min. /g fresh weight).

It is worthy to mention that, the untreated healthy and infected control recorded $(0.98$ recorded the lower activity (0.29 unite/30 min. /g fresh weight). It is worthy to mention that, the untreated healthy and infected control recorded $(0.14$ and 0.71 unite/30 $\mathrm{min} . / \mathrm{g}$ fresh weight). 


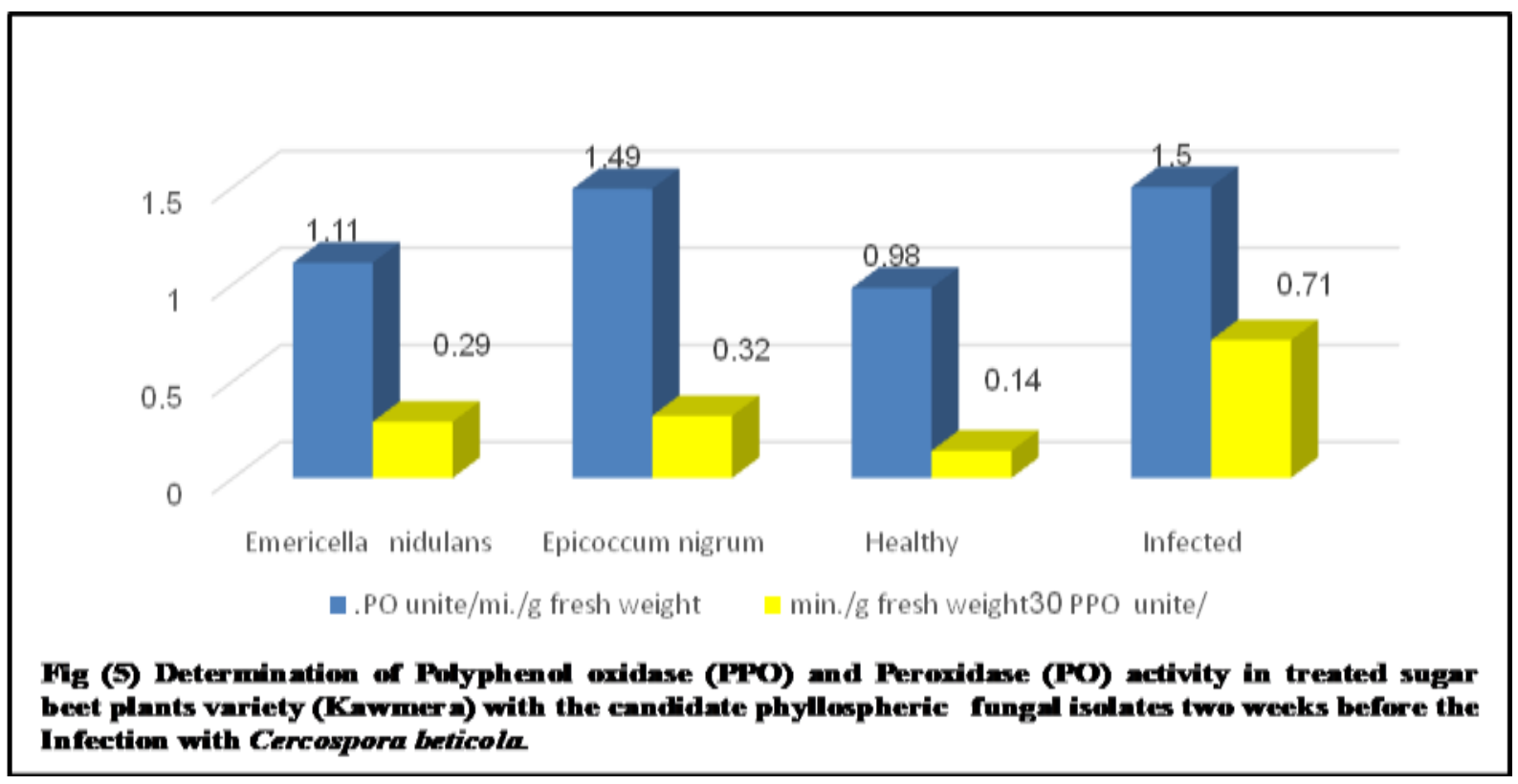

The data illustrated in Fig. (6) Show that, the isolate Epicoccum nigrum recorded the highest $\beta$ 1, 3 glucanase activity $(23.3 \mu \mathrm{M}$ of glucose released $/ \mathrm{ml}$ /hr.) while isolate Emericella nidulans recorded the lowest activity $(12.2 \mu \mathrm{M}$ of glucose released $/ \mathrm{ml} / \mathrm{hr}$ ) and the untreated healthy and infected control recorded (10.3 and $38.0 \mu \mathrm{M}$ of glucose released $/ \mathrm{ml} / \mathrm{hr}$ ).
While in chitinase activity the isolate of Emericella nidulans recorded the highest chitinase activity $(30.5 \mu \mathrm{M}$ of glucose released $/ \mathrm{ml} / \mathrm{hr})$.

While Epicoccum nigrum recorded the lower activity $(28.0 \mu \mathrm{M}$ of glucose released $/ \mathrm{ml} / \mathrm{hr}$.) and the untreated healthy and infected control recorded (13.9 and $52.1 \mu \mathrm{M}$ of glucose released $/ \mathrm{ml} / \mathrm{hr}$.).

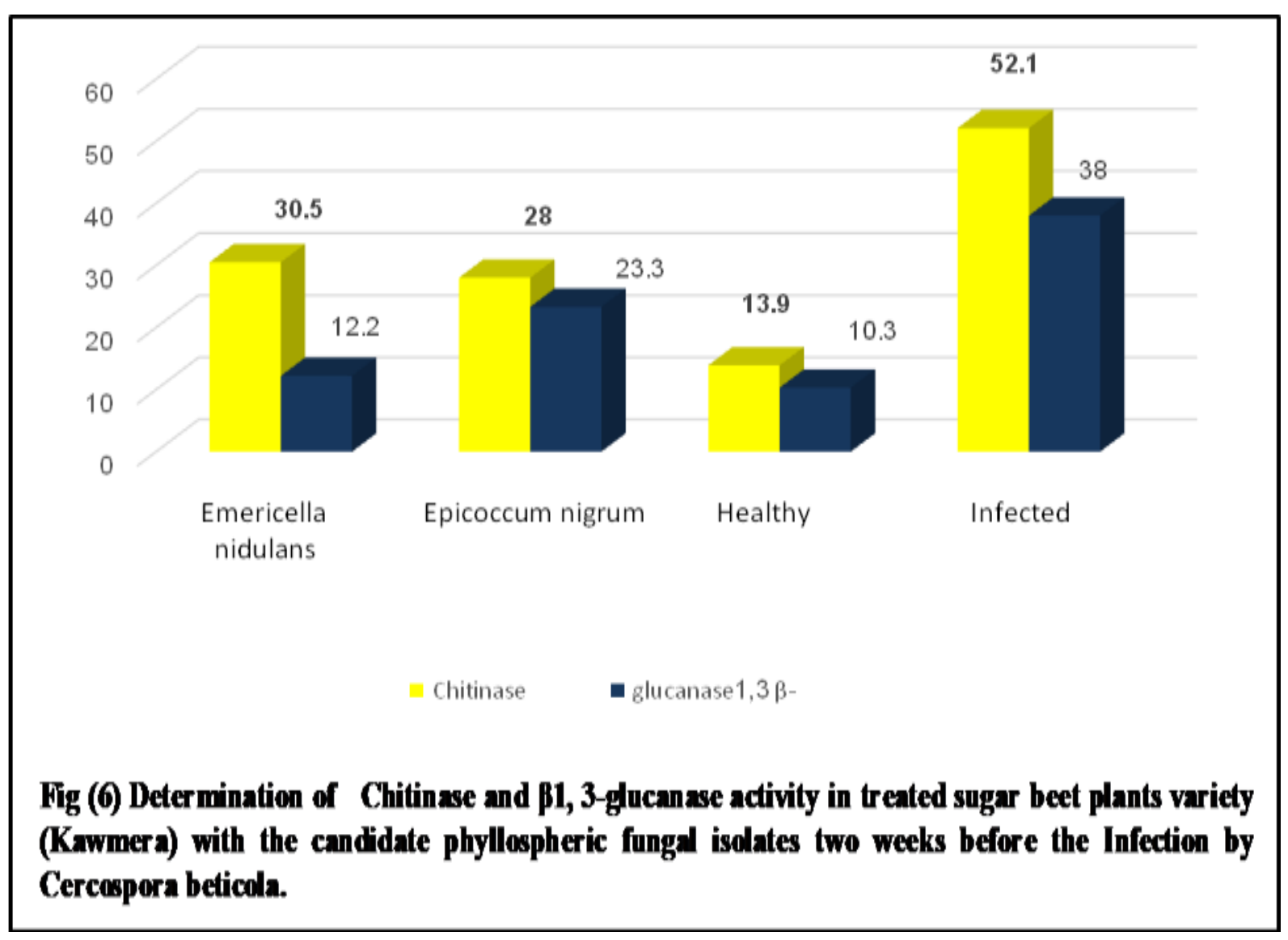




\section{Esh and Taghian}

\section{4- Effect of bio-agents on disease severity under field condition:}

The field experiment showed a different order in bio-control activity Table (3) and fig (7). The tested Emericellanidulans and Epicoccumnigrum recorded the highest significant increase of disease inhibition
(76.47 and 61.76) compared to the infected control treatment. It is worthy to mention that, isolate Emericellanidulans significantly increased the disease inhibition (76.47) compared to the fungicide Topsin M70 treatment which recorded disease severity inhibition of $70.59 \%$.

Table (3): Efficiency evaluation of the candidate phyllospheric fungal isolates on decreasing the severity of sugar beet cercospora leaf spot disease on sugar beet variety (Kawmera) when sprayed twice (two weeks intervals) before artificial infection with Cercospora beticola under field conditions during the season 2019-2020

\begin{tabular}{lll}
\hline Fungal Isolates & Disease severity & \% of disease inhibition \\
\hline Emericella nidulans & 0.80 & 76.47 \\
Epicoccum nigrum & 1.30 & 61.76 \\
Topsin M70 & 1.00 & 70.59 \\
Infected control & 3.40 & - \\
LSD at 0.05 & 0.35 & - \\
\hline
\end{tabular}

It was noticed that the disease severity in the infected control was higher in the greenhouse experiment (4.6) than in the field experiment (3.4)
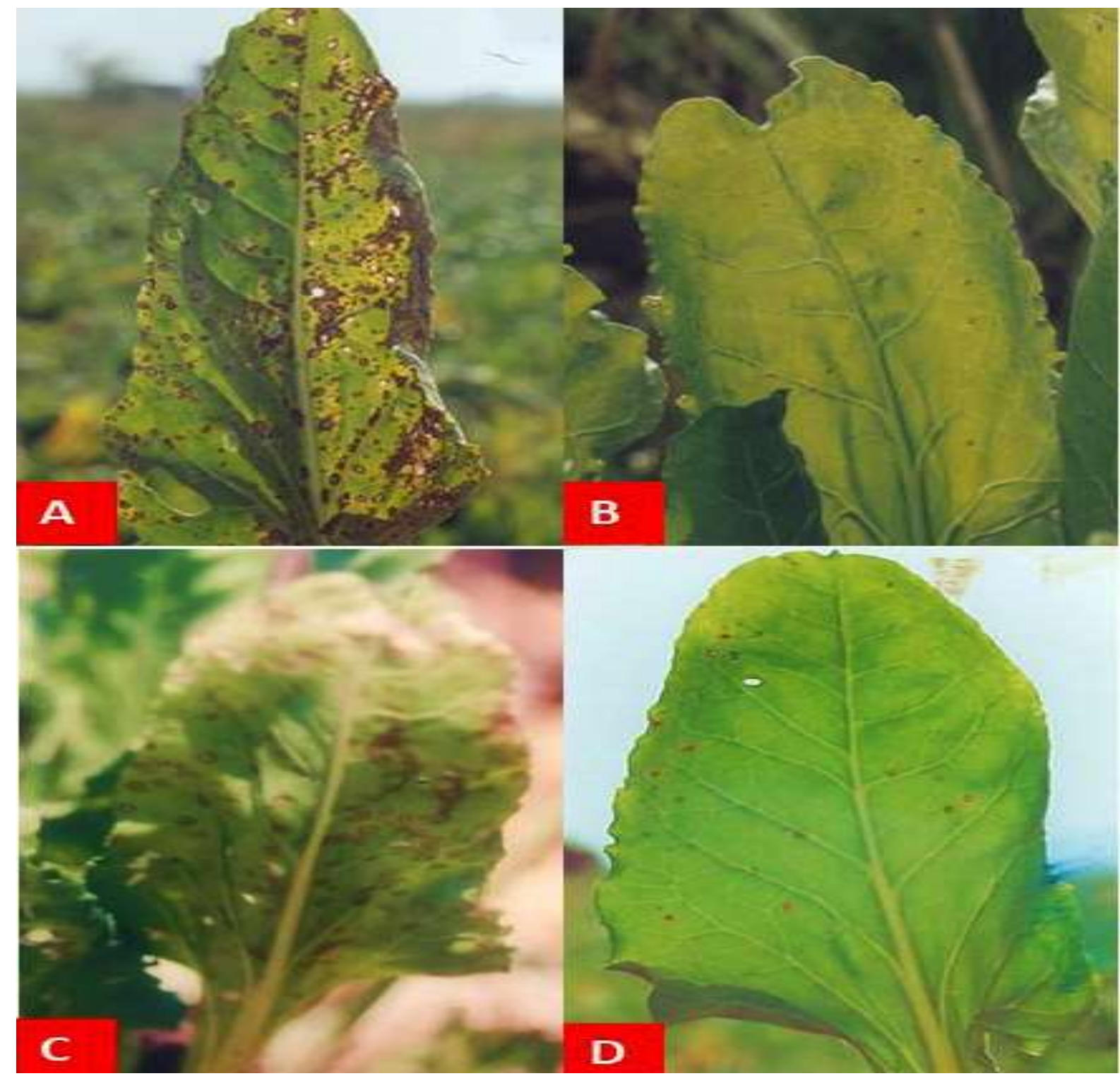

Fig. ( 7): Different effects of the bio- control active fungal isolates in field experiment, (A) the infected untreated control, B(Emericella nidulans), C (Epicoccum nigrum ); and D( Topsin M70) 


\section{DISCUSSION}

The obtained results from experimenting the different methods of duel culture from Emericella nidulans and Epicoccum nigrum isolates on the liner growth of Cercospora beticola (in vitro) showed a difference in the inhibitory percentage resulted from both methods. These results are in harmony with those reported by Agarry et al., (2005) who performed a comparison study on the efficiency of the antagonistic effect measurements in vitro between streak and volatile gases methods. They found a considerable variation in inhibitory activity. The zone of inhibition was more apparent in the streak method than in the other method. Many fungal species are known to emit low concentrations of gaseous substances, especially ones that have distinctiveobnoxious odours, and this has prompted appropriate chemical analyses of the fungal volatiles Bjurman and Kristensson, (1992).

Some of these volatile substances are common to many fungi, whereas others seem to be unique for one species (Schnurer et al., 1999 and Rapior et al., 2000).The obtained results also showed no significant difference between the disease reduction caused by the tested bio agents and the tested fungicide under field conditions.

These results are in agreement with those reported by Brewer and Larkin, (2005) who found that, some of the biological control treatments reduced disease equally to fungicides.

In the present study Emericella nidulans found to produce a significant IAA amount in vitro while the other isolate (Epicoccum nigrum) didn't produce any IAA. It was reported that the ability of different fungal genera to produce IAA was different. Gusmiaty et al 2019 reported many rhizosphere fungi such as Aspergillus, Trichoderma, Rhizopus, Penicillium, and Fusarium thatcan produce IAA in both in vivo and in vitro conditions.

The tested fungal bioagents were proved to produce chitinases, b-1, 3-glucanases in both in vitro and in vivo studies. Fungal cell wall degradation is typically caused by a range of chitinases, b-1, 3glucanases and proteases or, in case of hyperparasites of oomycota, cellulases. Such a necrotrophic hyper-parasitism with invasion of killed host cells is frequently observed by microscopy and electron microscopy (Jeffries, 1995).

Antagonistic activity of selected bio-agents showed a degree of inhibition of $\mathrm{C}$. beticola. The growth inhibition of $\mathrm{C}$. beticola by antagonist fungi is possibly attributed to the secretion of antibiotics by the bio-agent (Upadhyay and Rai,1987) or other inhibitory substances such as geodin, terricin, terric acid, aspergillic acid, dermadin, etc. (Brian et al., 1945). The degree of effectiveness varies according to the nature, quality, and quantity of antibiotics/inhibitory substances secreted by the antagonists (Dennis and Webster, 1971a, b and Skidmore and Dickinson, 1976).
Under greenhouse and field conditions, all the tested isolates significantly reduced the CLS severity compared to the untreated control plants. Generally, it was noticed that, the disease severity in the greenhouse was always higher than in the field. Also the bio-control activity of the tested isolates differed in both greenhouse and field experiments, these results in agreement with those reported by Whitney and Duffus, (1986) which reported that, the relative humidity above $90 \%$ and temperatures above $15.5^{\circ} \mathrm{C}$ are required for Cercospora spore germination. Steinkamp et al., (1979) studied the C. beticola infection process determining that $\mathrm{C}$. beticola infection begins by attachment of the conidia to the leaf surface and subsequent germination and entry of a germ tube through stomata during periods of leaf wetness. Rathaiah, (1977) determined that hydrotropism was important in the ability of the germ tube to locate stomata. A higher relative humidity in the stomatal opening as compared to lower ambient levels was correlated with infection through stomates. Stomata do not need to be open to facilitate fungal entry.

Generally in the present study, foliar treatment with fungal isolates increased the activities of various defense enzymes when the plants were inoculated with the pathogen. Romero et al., (2003) reported that, fungal bio-control agents against cucurbit powdery mildew performed better under greenhouse conditions of high relative humidity (90-95\% RH).

The activity of peroxidase (PO) and polyphenol oxidase (PPO) Ramamoorthy et al., (2002) reveled that, Po and PPO declined rapidly in tomato after 4 days of inoculation with Fusarium oxysporum f.sp. lycopersici compared to bacterized plants challenged with the pathogen. PO and PPO catalyze the last step in the biosynthesis of lignin and other oxidized phenols.

On the other hand, The PO activity increased rapidly in cucumber roots treated with $\mathrm{P}$. corrugata challenged with P. aphanidermatum . Enhanced PO activity is very often associated with resistance and lignin production. PO-generated hydrogen peroxide may function as an anti-fungal agent in disease resistance.

Hydrogen peroxide inhibits pathogens directly or it may generate other free radicals that are antimicrobial in nature Reuveni et al., 1992. The data obtained from this work would encourage the use of biological control against CLS disease as a eco-friendly alternative to the use of fungicides. nonpathogenic, phyllosphere-colonizing Bacillus mycoides,

\section{REFFRENCE}

Agarry, O. O., Olaleye, M. T., and M. Bello, C. O. 2005. Comparative antimicrobial activities of aloe vera gel and leaf. African Journal of Biotechnology. 4: 1413-1414. 


\section{Esh and Taghian}

Bargabus, R. L., Zidack ,N. K., Sherwood, J. W., and Jacobsen,. B. J. 2002. Characterization of systemic resistance in sugar beet elicited by a Physiological and Molecular Plant Pathology. 61: 289-298.

Battilani, P., Beltrami, G., Meriggi, P., Ponti, I.A., Rossi, V., Rosso, F., Tugnoli, V., and Zocca, A. 1990. Nuovi indrizzi di difesa anticercosporica. L'Informatore Agrario. 46: 53-70.

Bjurman., J. and Kristensson, J. 1992. Volatile production by Aspergillus versicolor as a possible cause of odor in houses affected by fungi. Mycopathologia. 118: 173-178.

Bollage, M.D., Rozycki, D.M., and Edelstein, J. S. 1996. Protein methodes.Wiley-Liss, Inc., New York. : 413.

Brewer, M.T., and Larkin, R. P. 2005. Efficacy of several potential biocontrol organisms against Rhizoctonia solani on potato. Crop Prot. 24: 939950.

Brian, P.W., Hemming, H.G., McGowan, J.C. 1945. Origin of toxicity in warhen health soil. Nature, 155: 637.

Bric, J. M., Bostock, R. M., and Silverstone, S. E. 1991. Rapid in situ assay for indole acetic acid production by bacteria immobilized on an itrocellulose membrane. Appl. Eniron. Microbiol. 57: 535-538.

Campell, L.L, and Gen Williams, J. 1951. A study of chitin-decomposing microorganisms of marine origin .J Gen Microbiol. 5: 894-905.

Dennis, C., and Webester, J. 1971a. Antagonistic properties of species group of Trichoderma I. Production of volatile antibiotics. Trans. Brit. Mycol.Soc. 57: 41-48.

Dennis, C., and Webster, J. 1971b. Antagonistic properties of species group of Trichoderma II. Production of volatile antibiotics. Trans. Brit. Mycol. Soc. 57: 63-69.

Douglas, P., Collins, A., Barry, J. Jacobsen, B., and Maxwell, B. 2003. Spatial and temporal population dynamics of a phyllosphere colonizing Bacillus subtilis biological control agent of sugar beet cercospora leaf spot. Biological Control. 26: 224-232.

Esh, A. M. H. 2005. Controlling sugar beet cercospora leaf spot disease using environment friendly calcium salts. Zagazig J. Agric. Res. 32: 1517-1535.

Gusmiaty, A., Restu, M., and Payangan, R. Y. 2019. Production of IAA (Indole Acetic Acid) of the rhizosphere fungus in the Suren community forest stand. IOP Conf. Ser.: Earth Environ. Sci. 343: 12-22.

Jacobsen, B. J., Larson, B., Zidack, N. K., Ansley, J., Eckhoff, J.L.A., and Bergman, J. 2002. Integrated management of Cercospora leaf spot.Sugarbeet Res. Ext. Rep. 33: 235-240.

Jeffries, P. 1995. Biology and ecology of mycoparasitism. Can. J. Bot. 73.
Kar, M., and Mishra, D. 1976. Catalase, peroxidase and polyphenoloxidase activities during rice leaf senescence. Plant Physiology. 57: 315-319.

Knudsen, G.R., and Hudler, G.W. 1987 .Use of a computer simulation model to evaluate a plant disease bio-control agent, Ecological.Modelling. 35(1-2): 45-62.

Larenaa, R.A., Torresb, M., De-Cala, P., Liñána, P.Melgarejoa, A. Domenichinic, J.F. Bellinic, J., Mandrind, X., Lichoud, J., Ochoa, de-Eribee. 2005. Biological control of postharvest brown rot (Monilinia spp.)of peaches by Weld applications of Epicoccum nigrum. Biological Control. 32: 305-310.

Larson, B. 2004. Integrated management of Cercospora leaf spot. M.S.thesis. Montana State University, Bozeman.

Lim, H., Kim, Y., and Kim, S. 1991. Pseudomonas stutzeri YLP-I genetic transformation and antifungal mechanism against Fusarium solani, an agent of plant root rot .Appl. Environ. Microbiol. 57: 510-516.

Malik, C. P., and Singh, M.B. 1990. Extraction and estimation of amino acids and kito acids. In: Plant Enzymology and histo-Enzymology.New DelhiLud Hana, India. : 1284-1290. doi: 10.1139/b95389.

Matta, A., and Dimond, A.E. 1963. Symptoms of Fusarium Wilt in relation to quantity of fungus and enzyme activity in tomato stems.Phytopathology. 53: 574-587.

Montealegre, J. R., Reyes, R., Pérez, L., Herrera, R., Silva, P., and Besoain, X. 2003. Selection of bioantagonistic bacteria to be used in biological control of Rhizoctonia solani in tomato. Electronic Journal of Biotechnology. 6: 116-127.

Naguib, M.I. 1964. Effect of Seivn on the carbohydrate and nitrogen metabolism during the germination of cotton seeds. Ind. J. Agric. Sci. 35: 179-185.

Naguib, M.I. 1965. Effect of maleic hydrazine on the nitrogen metabolismduring the germination of cotton seed. Ind. J. Exp. Biol. 2: 149-152.

Nelson, N. 1944. A photometric adaptation of the Somogy method for the determination of glucose. J. Biol. Chem. 152: 375-380.

Peng, G. and Sutton, J. C. 1991. Evaluation of microorganisms for biocontrol of Botrytis cinerea in strawberry. Can. J. Plant Pathology. 13: 247257.

Picard, K., Tirilly, Y., and Benhamou, N. 2000. Cytological effects of cellulases in the parasitism of Phytophthora parasitica by Pythium oligandrum. Applied and Environmental Microbiology. 66: 4305-4314.

Punja, Z.K., and Utkhede, R.S. 2003. Using fungi and yeasts to manage vegeTable crop diseases. Trends in Biotechnology. 21: 400-407.

Ramamoorthy, V., Raguchander, T., and Samiyappan, R. 2002. Induction of defense related proteins in tomato roots treated with 
Pseudomonas fluorescens Pf1 and Fusarium oxysporum f. sp. lycopersici Plant and Soil. 239: 55-68.

Rathaiah, Y. 1977. Stomatal tropism in Cercospora beticola in sugar beet. Phytopathology. 67: 358362.

Reissig, J. L., Stringer, J. L., and Leloir, L. F. 1955. A modified colorimetric method for the estimation of $\mathrm{N}$-acetylaminosugars.J. Biol. Chem. 217: 959-966.

Reuveni, R., Shimoni, M., and Crute, I. R. 1992. Peroxidase activity as a biocontrol marker for resistance of muskmelon to Pseudopernospora cubensis. Phytopathology 82: 749-753.

Romero, D., Rivera, M. E., Cazorla, F. M., de Vicente, A., and Perez, A.G. 2003. Effect of mycoparasitic fungi on the development of Sphaerotheca fusca in melon leaves. Mycological Research. 107: 64-71

Schnurer, J., Olsson, J., and Borjesson, T. 1999. Fungal volatiles as indicators of food and feeds spoilage. Fungal Genetic. Biology. 27: 209-217.

Skidmore, A.M., and Dickinson, C.H. 1976. Colony interactions and hyphal interference between
Septoria nodorum and phylloplane fungi. Trans.Brit. Mycol. Soc. 66: 57-64.

Soltis, D. E., and Soltis, P. S. 1990. Isozymes in plant biology. Dioscorides press, Portland, Oregon. : 259.

Steinkamp, M. P., Martin, S.S., Hoefert, L.L., Ruppel, G.E. 1979. Ultrastructure of lesions produced by Cercospora beticola in leaves of Beta vulgaris. Physiological Plant Pathology. 15: 1326.

Upadhyay, R.S., and Rai, B. 1987. Studies on antagonism between Fusarium udum, Butler and root region microflora of pigeon pea. Plant Soil 101: 79-93.

Vereijssen, J., Schneider, J.H.M., Termorshuizen, A.J., and Jeger, M. J. 2003. Comparison of two disease assessments keys to assess Cercospora beticola in sugar beet. Crop Protection. 22: 201209.

Whitney, E.D., and Duffus, J.E. 1986. Compendium of beet diseases and insects. The American Psychopathological Society-APS Press. : 8-9.

\section{الملخص العربى}

دور فطري إبيكوكم نيجرام و إميريسيلا نيديولانس في مقاومة مرض التبقع السيركوسبوري فى بنجر السكر أيمن محمد حسني عش* وشاديه تغيان

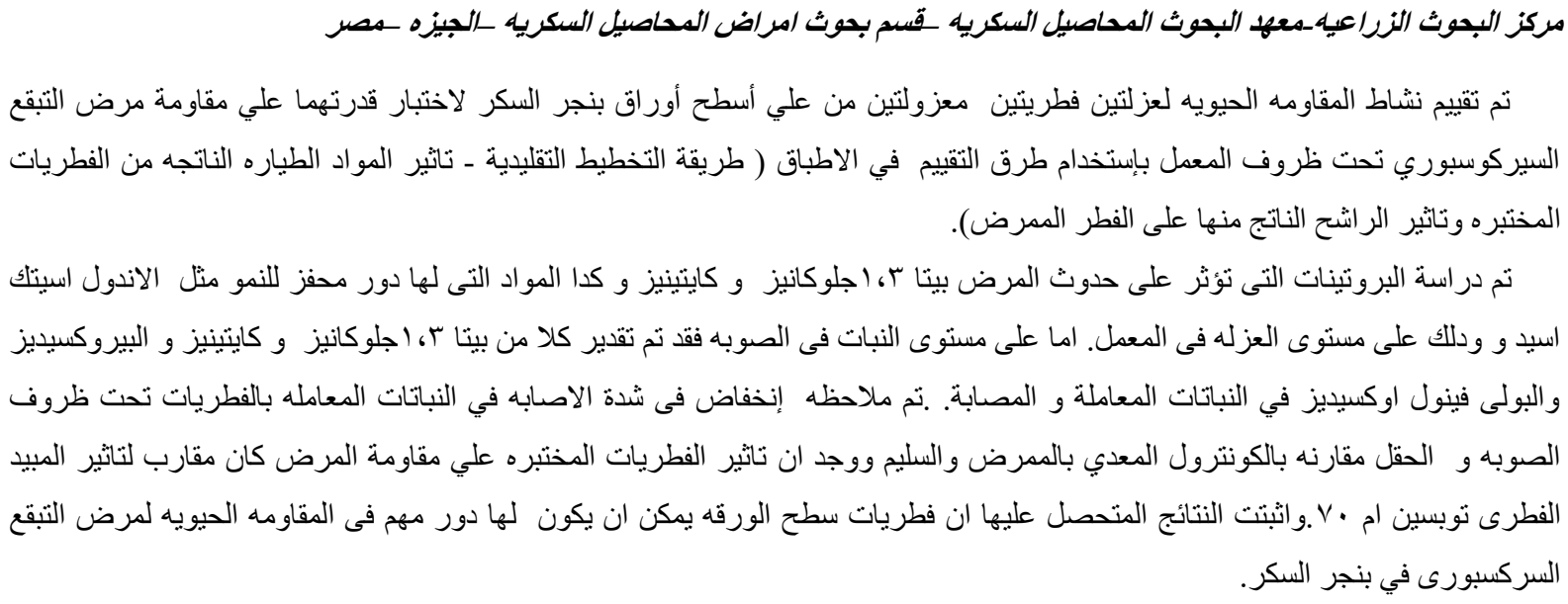

